\title{
Combined immune checkpoint protein blockade and low dose whole body irradiation as immunotherapy for myeloma
}

Weiqing Jing ${ }^{1}$, Jill A Gershan ${ }^{1}$, James Weber ${ }^{1}$, Dominique Tlomak', Laura McOlash', Catherine Sabatos-Peyton ${ }^{2}$ and Bryon D Johnson ${ }^{1 *}$

\begin{abstract}
Background: Multiple myeloma is characterized by the presence of transformed neoplastic plasma cells in the bone marrow and is generally considered to be an incurable disease. Successful treatments will likely require multi-faceted approaches incorporating conventional drug therapies, immunotherapy and other novel treatments. Our lab previously showed that a combination of transient lymphodepletion (sublethal whole body irradiation) and PD-1/PD-L1 blockade generated anti-myeloma T cell reactivity capable of eliminating established disease. We hypothesized that blocking a combination of checkpoint receptors in the context of low-dose, lymphodepleting whole body radiation would boost anti-tumor immunity.
\end{abstract}

Methods: To test our central hypothesis, we utilized a $5 T 33$ murine multiple myeloma model. Myeloma-bearing mice were treated with a low dose of whole body irradiation and combinations of blocking antibodies to PD-L1, LAG-3, TIM-3, CD48 (the ligand for 2B4) and CTLA4.

Results: Temporal phenotypic analysis of bone marrow from myeloma-bearing mice demonstrated that elevated percentages of PD-1, 2B4, LAG-3 and TIM-3 proteins were expressed on T cells. When PD-L1 blockade was combined with blocking antibodies to LAG-3, TIM-3 or CTLA4, synergistic or additive increases in survival were observed (survival rates improved from $\sim 30 \%$ to $>80 \%$ ). The increased survival rates correlated with increased frequencies of tumor-reactive CD8 and CD4 T cells. When stimulated in vitro with myeloma cells, CD8 T cells from treated mice produced elevated levels proinflammatory cytokines. Cytokines were spontaneously released from CD4 T cells isolated from mice treated with PD-L1 plus CTLA4 blocking antibodies.

Conclusions: These data indicate that blocking PD-1/PD-L1 interactions in conjunction with other immune checkpoint proteins provides synergistic anti-tumor efficacy following lymphodepletive doses of whole body irradiation. This strategy is a promising combination strategy for myeloma and other hematologic malignancies.

Keywords: Low dose whole body irradiation, Immune checkpoint proteins, Blockade, PD-L1, TIM-3, LAG-3, CTLA4, 2B4, Myeloma

\section{Background}

Reports of immunotherapy-induced clinical responses have brought the study of tumor immunity front and center in the mission to eliminate cancer. Central to tumor immunity is the killing potential of activated tumor-specific T cells. Tumor-specific $\mathrm{T}$ cells can be detected in both preclinical

\footnotetext{
* Correspondence: bjohnson@mcw.edu

'Division of Hematology/Oncology/Transplant, Department of Pediatrics, Medical College of Wisconsin, Milwaukee, WI 53226, USA

Full list of author information is available at the end of the article
}

animal models and cancer patients, but due to multiple immune suppressive factors within the tumor microenvironment, $\mathrm{T}$ cells fail to maintain an activated state against progressing tumor and are rendered tolerant or exhausted. T cell activation is initiated through tumor antigen recognition by the T cell receptor (TCR) and is regulated by a balance of activation and inhibitory intracellular signals. These signals are initiated by engagement of co-stimulatory and co-inhibitory receptors with their cognate ligands. One of the promising approaches to induce and maintain 
tumor-specific $\mathrm{T}$ cells in an activated state is to interfere with signaling through inhibitory (also referred to as immune checkpoint) receptors.

There are multiple known $\mathrm{T}$ cell checkpoint receptors, and there is evidence that blocking interaction of these receptors with their respective ligands can increase antitumor immune responses. One of the most studied checkpoint receptors is CTLA4. Cell surface CTLA4 expression is rapidly upregulated when T cells are activated, and it is constitutively expressed on Foxp $3^{+}$regulatory $\mathrm{T}$ cells [1]. Signaling through CTLA4 arrests T cell activation by outcompeting co-stimulatory receptors (CD80 and CD86) for binding to CD28. CTLA4 binding to CD28 results in reduced $\mathrm{T}$ cell survival, cytokine production and $\mathrm{T}$ cell cycle arrest [2]. Testament to the importance of CTLA4 in dampening T cell activation is the occurrence of a lethal polyclonal lymphoproliferative disease that occurs in CTLA4 knockout mice [3]. Antagonistic antiCTLA4 antibodies have been extensively tested in cancer models as a strategy to activate anti-tumor immunity, and CTLA4 was the first immune checkpoint targeted in the clinic for cancer therapy. The anti-tumor effects associated with blocking CTLA4 in vivo have been shown to involve depletion of regulatory $\mathrm{T}$ cells as well as restoring effector T cell function $[4,5]$. Notably, CTLA4 blockade results in increased ratios of effector CD8 T cells to regulatory $\mathrm{T}$ cells in tumors, possibly due to higher levels of CTLA4 expression by regulatory T cells [4]. In 2010, a phase III randomized controlled clinical trial showed prolonged survival of metastatic melanoma patients when treated with the anti-CTLA4 antibody ipilimumab [6]. In melanoma patients, blocking CTLA4 produced a host of immune-related toxic side effects (referred to as immune-related adverse events). However, based on the promising responses in melanoma patients, ipilimumab was the first checkpoint-blocking antibody to be FDA approved (for the treatment of melanoma).

Our laboratory has focused on blocking the checkpoint receptor programmed death receptor-1 (PD-1) pathway in the treatment of myeloma. PD-1 (CD279) is an immunoglobulin superfamily transmembrane receptor that is expressed on activated T cells, regulatory T cells, B cells and NK cells. Ligands for PD-1 include PD-L1 (B7-H1, CD274) and PD-L2 (B7-DC, CD273) [7]. PD-L2 expression is restricted to hematopoietic cells, notably myeloid cells including dendritic cells and macrophages, but PD-L1 is broadly expressed on hematopoietic and nonhematopoietic cells as well as on a variety of murine and human malignancies [8,9]. Most of data showing the anti-tumor efficacy induced by blocking the PD-1/ PD-L1 inhibitory receptor axis has been generated from preclinical and clinical studies involving solid tumors. Preclinical studies have shown that blocking the PD-L1/PD-1 axis with anti-PD-L1 or anti-PD-1 antibodies promotes anti-tumor $\mathrm{T}$ cell responses in pancreatic carcinoma [10], B16 melanoma [11], and CT26 colon carcinoma [12]. In a recent clinical study, patients with colorectal cancer, renal cell carcinoma or melanoma showed objective responses to anti-PD-L1 therapy [13]. Patients with PD-L1 $1^{+}$tumors, but not PD-L1 ${ }^{-}$tumors, showed objective responses when treated with an anti-PD-1 blocking antibody [14]. Clinically, combining anti-CTLA4 (ipilimumab) with anti-PD-1 (nivolumab) antibodies resulted in even greater antitumor efficacy, as tumor regression occurred in $80 \%$ of patients with advanced melanoma [15]. Importantly, immune adverse events were qualitatively similar to that experienced with prior treatment of either antibody alone.

Less well-characterized T cell immune checkpoint receptors include lymphocyte activating gene 3 (LAG-3 or CD223), $\mathrm{T}$ cell immunoglobulin and mucin domain 3 (TIM-3), 2B4 (CD244), and others. LAG-3 is a member of the immunoglobulin (Ig) superfamily that binds to MHC class II molecules, and has recently been reported to also bind L-selectin [16]. LAG-3 is expressed on activated and tolerized T cells, NK cells, plasmacytoid dendritic cells, and regulatory $\mathrm{T}$ cells and it is known to negatively regulate the expansion of activated $\mathrm{T}$ cells $[17,18]$. Preclinical studies have shown that combined treatment of LAG-3 and PD-1 blocking antibodies provided a synergistic anti-tumor effect [19]. The TIM family of transmembrane receptor proteins includes several members (TIM-1, 2, 3 and 4 in mice, but only TIM-1, 3 and 4 are known to be expressed in humans). Ligation of TIM-1 regulates Th2 CD4 T cell responses, and in mice, TIM-1 promotes CD4 T cell activation [20]. TIM3 is a checkpoint receptor that is co-expressed on PD- $1^{+}$ CD8 $\mathrm{T}$ cells in mice harboring solid or hematologic malignancies [21,22]. The ligand for TIM-3 is galectin-9 which is expressed by multiple tumors. Reduced galactin- 9 expression correlates with reduced disease progression in a majority of solid tumors [23]. PD- $1^{+} \mathrm{TIM}-3^{+}$T cells derived from patients with melanoma, non-small cell lung cancer or non-Hodgkin's lymphoma are defective in proliferation and cytokine production [24-26]. TIM-3 is also expressed on regulatory T cells, monocytes, NK cells, and dendritic cells [27]. Data suggests that TIM-3 can play antiinflammatory or pro-inflammatory roles in cells depending on the physiologic setting $[28,29]$. In a preclinical mouse B16F10 melanoma model, combined blockade of TIM-3 and PD-1, or TIM-3 and CTLA4, was more effective in prolonging survival than blocking either protein alone [30]. In addition, the combination of anti-CTLA4, anti-TIM-3 and anti-LAG-3 produced further suppression of B16F10 tumor growth [30]. These data demonstrate a mechanistic synergy when multiple inhibitory receptors are blocked.

2B4 (CD244) engagement with CD48 was originally described as facilitating CD8 $\mathrm{T}$ cell proliferation [31]. Recent data examining hepatitis $\mathrm{C}$-virus ( $\mathrm{HCV}$ )-specific 
CD8 T cells showed that crosslinking 2B4 on CD8 T cells with low versus high 2B4 expression increased or decreased proliferation, respectively, and 2B4 blockade preferentially increased proliferation of HCV CD8 T cells with high 2B4 expression [32]. Similar to other checkpoint proteins, 2B4 is upregulated on exhausted virus-specific CD8 $\mathrm{T}$ cells [33]. Together these data suggest that 2B4 plays a role in the regulation of CD8 T cells.

Despite the promising results afforded by blocking CTLA4 and the PD-1/PD-L1 axis in the treatment of solid tumors, targeting these checkpoints in hematologic malignancies has been relatively understudied. Multiple myeloma is a hematologic malignancy involving plasma cells. In humans, PD-L1 is expressed on CD $138^{+}$malignant plasma cells [34-38]. We have shown that PD-1 is upregulated on peripheral blood and bone marrow in myeloma patients up to 30 days following autologous transplant [35]. In humans, blocking the PD-L1/PD-1 axis may act to prevent inhibitory signaling when effector $\mathrm{T}$ cells engage with tumor cells and when $\mathrm{T}$ cells are undergoing homeostatic expansion.

Our preclinical studies have demonstrated improved anti-myeloma $\mathrm{T}$ cell immunity when the PD-1/PD-L1 axis is blocked. Using a murine model of myeloma, we showed that administration of an anti-PD-L1 blocking antibody elicits rejection of PD-L1 expressing tumor cells. When anti-PD-L1 was administered immediately following hematopoietic stem cell transplantation in combination with a tumor cell-based vaccine, myeloma was eliminated in approximately $40 \%$ of treated mice [35]. We also reported that $5 \mathrm{~T} 33$ tumor was eliminated in approximately $50 \%$ of mice when treated with anti-PDL1 following radiation-induced lymphopenia [39]. Based on these data and the data of others, we hypothesized that blocking a combination of checkpoint receptors in the context of lymphodepleting radiation would boost antitumor immunity. The results presented here confirm the hypothesis and show that PD-1/PD-L1 blockade in combination with either TIM-3, LAG-3 or CTLA4 blockade synergistically improves the survival of myeloma bearing mice.

\section{Results}

Increased PD-1, TIM-3, LAG-3 and 2B4 expression on CD4 and CD8 T cells directly correlates with myeloma burden Our previous work demonstrated that the PD-1/PD-L1 pathway is important in suppressing immune responses to 5T33 myeloma, and that PD-1 expression on T cells is related to $5 \mathrm{~T} 33$ burden in the myeloma-resident tissues (bone marrow, spleen and liver) [35,39]. Besides expression of the immune checkpoint protein PD-1, T cells within tumor environments may develop a dysfunctional phenotype accompanied by the increased expression of other checkpoint proteins. We therefore examined CD4 and CD8 T cells for the expression of other checkpoint receptors over time in myeloma-bearing animals. GFP 5 T33 cells could be observed in the bone marrow as early as 7 days after iv inoculation, with increasing accumulation of myeloma cells over time (Figure 1A). When myeloma-bearing mice became moribund (29-38 days after 5T33 inoculation), $20-35 \%$ of the cells in the bone marrow consisted of $\mathrm{GFP}^{+}$tumor cells. As previously described [39], there was a significant increase in the percentages of $\mathrm{PD}-1^{+}$bone marrow-derived CD4 and CD8 $\mathrm{T}$ cells as early as 21 days after myeloma inoculation (Figure 1B). As myeloma burden progressed, the percentages of bone marrow-derived PD- $1^{+}$CD4 and CD8 T cells increased to $40-70 \%$ and $30-50 \%$, respectively. Similar to the increase in PD-1 expression, increasing percentages of $\mathrm{T}$ cells in the bone marrow expressed TIM-3, LAG-3 and 2B4 as myeloma burden progressed (Figure 1B). In contrast, percentages of T cells expressing TIM-1 or BTLA did not increase over time. Similar results were also observed in the spleen (Additional file 1: Figure S1). Together, these data show that there is upregulated expression of multiple checkpoint receptors on T cells in tissues where myeloma cells are present, and that an accumulation of checkpointexpressing $\mathrm{T}$ cells occurs over time. In order to show that checkpoint receptors are co-expressed on $\mathrm{T}$ cells, CD4 and CD8 cells in the bone marrow of moribund mice were analyzed for PD-1, TIM-3, LAG-3 and 2B4 expression using multicolor flow cytometry. For CD8 $\mathrm{T}$ cells (Figure 1C, top row), PD-1 was co-expressed on $85 \%$ of TIM- $3^{+}$cells, $67 \%$ of LAG- $3^{+}$cells, and $51 \%$ of $2 B 4^{+}$cells. For CD4 T cells (Figure 1C, bottom row), co-expression of PD-1 was observed on $90 \%$ of $\mathrm{TIM}^{+} 3^{+}$cells, $47 \%$ of LAG- $3^{+}$cells, and $44 \%$ of $2 \mathrm{~B} 4^{+}$cells. Notably, there were also $\mathrm{PD}-1^{+}$cells that did not co-express the other checkpoints (upper left quadrants in Figure 1C), as well as major subsets of $\mathrm{LAG}_{-}{ }^{+}$and $2 \mathrm{~B}^{+}$cells that did not co-express PD-1 (lower right quadrants in Figure 1C).

Next, we determined whether checkpoint ligands for TIM-3, LAG-3 and CTLA4 were expressed on the tumor and cells within the tumor microenvironment (i.e., spleen). PD-L1 is highly expressed on 5T33 myeloma cells [35], but the ligands for TIM-3 (galectin-9), LAG-3 (MHC class II), and CTLA4 (CD80) are not (Additional file 2: Figure S2A). In vitro irradiation with 500 cGy did not change the galectin-9, MHC class II or CD80 expression on 5T33 myeloma cells. Not surprisingly, galectin-9, MHC class II and CD80 is present on a variety of cells in the tumor microenvironment including B cells, macrophages, DCs and monocytes (Additional file 2: Figure S2B).

\section{Immune checkpoint protein expression is increased on} CD8 $\mathrm{T}$ cells in mice treated with lymphodepleting radiation and anti-PD-L1

We previously showed that blocking the PD-1/PD-L1 axis with a PD-L1-specific monoclonal antibody synergized 


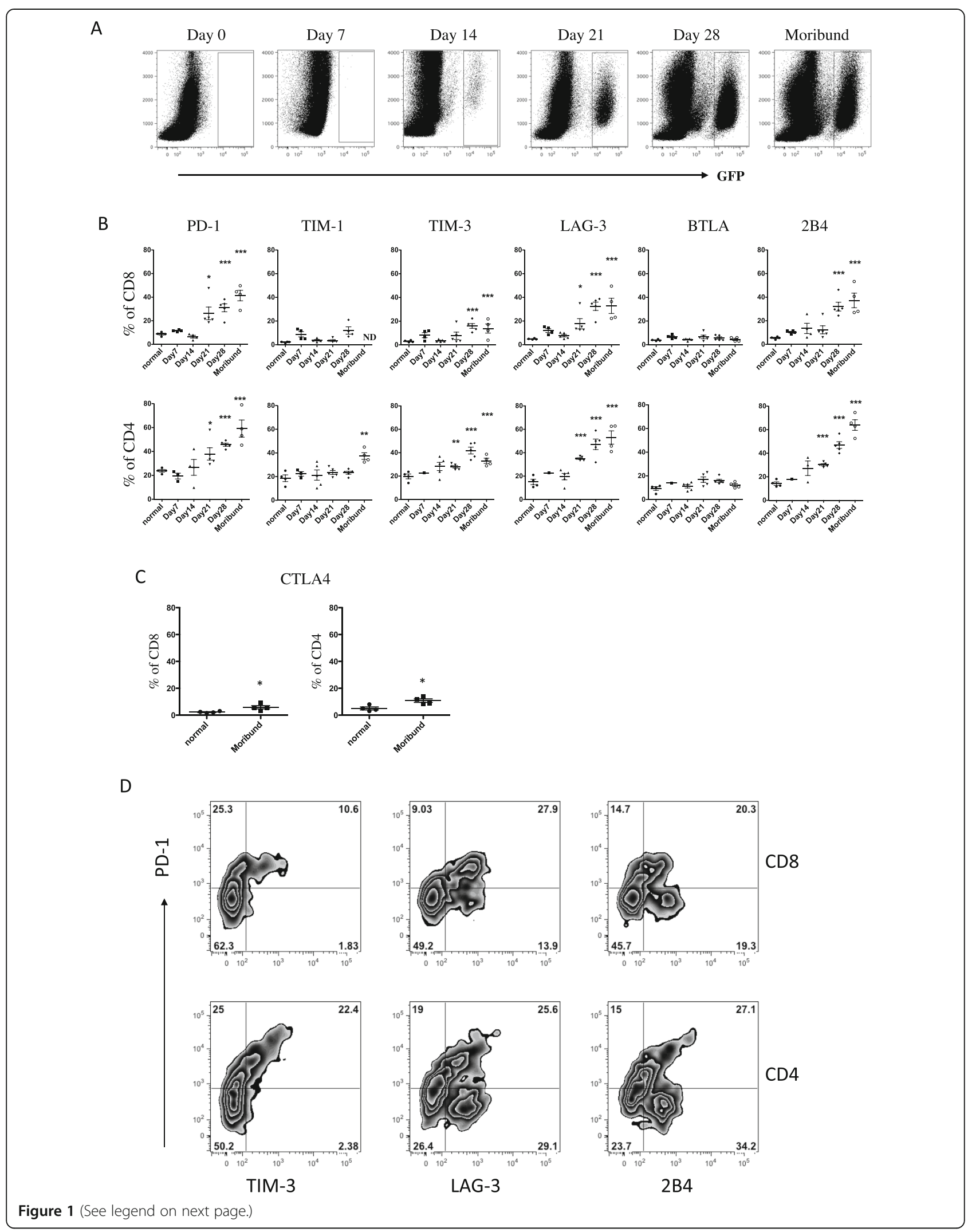


(See figure on previous page.)

Figure 1 Expression of immune checkpoint proteins on T cells in bone marrow of myeloma bearing mice over time. KaLwRij mice were inoculated with $2 \times 10^{6}$ 5T33-GFP cells iv. Myeloma bearing mice were euthanized between days 7 and 28 and when moribund at days $29-40$ after myeloma injection. Femoral bone marrow cells were harvested and (A) GFP tumor cell accumulation was monitored by flow cytometry. CD4 ${ }^{+}$ and $\mathrm{CD}^{+}{ }^{+}$cells in the bone marrow were analyzed by flow cytometry for expression of (B) PD-1, TIM-3, LAG-3, BTLA and 2B4 at each of the time points indicated, or for surface expression of (C) CTLA4 when animals were moribund. T cells harvested from naïve non-myeloma bearing mice were analyzed as controls. Immune checkpoint protein percentages were calculated based on isotype controls. (D) Expression of TIM-3 and PD-1, LAG-3 and PD-1 or 2B4 and PD-1 on gated CD8 ${ }^{+}$or $C D 4^{+} T$ cells harvested from the BM of moribund mice. Data shown are representative of more than four independent analyses. ${ }^{*} p<0.05,{ }^{* *} p<0.01,{ }^{* * *} p<0.001$ as compared to $T$ cells from naïve non-myeloma bearing mice.

with lymphodepleting whole body irradiation (WBI) to facilitate a $\mathrm{T}$ cell-mediated anti-myeloma response [39]. To determine the influence of this treatment on $\mathrm{T}$ cell immune checkpoint expression, mice with established myeloma were treated with 500 cGy WBI 7 days after 5 T33 inoculation, followed by three treatments with anti-PDL1 or control IgG on days 5, 7 and 12 after WBI. On day 14 after WBI, CD8 T cells were harvested from bone marrow and analyzed for expression of PD-1, TIM-3, LAG-3 and $2 \mathrm{~B} 4$ by flow cytometry. There were significant increases in the percentages of CD8 $\mathrm{T}$ cells that expressed TIM-3, LAG-3 or 2B4 in mice treated with anti-PD-L1 as compared to controls treated with IgG1 (Figure 2A). Interestingly, the mice treated with anti-PD-L1 also had a marked increase in percentages of $\mathrm{PD}-1^{+} \mathrm{CD} 8 \mathrm{~T}$ cells (Figure $2 \mathrm{~B}$ ), and relatively large percentages of the $\mathrm{PD}-1^{+}$ cells co-expressed TIM-3 (52\%), LAG-3 (60\%) or 2B4 (40\%) (Figure 2B).

\section{Blocking PD-L1 in combination with TIM-3, LAG-3 or CTLA4 blockade synergize to improve the survival of lymphodepleted myeloma-bearing mice}

Since multiple immune checkpoint proteins are upregulated on $\mathrm{T}$ cells in myeloma-bearing mice (Figure 1), and blocking the PD-L1/PD-1 axis in lymphodepleted animals induces increased expression of LAG-3, TIM-3 and 2B4 checkpoint proteins (Figure 2), we hypothesized that anti-myeloma immunity would be enhanced by blocking combinations of immune checkpoints. Mice were inoculated with $2 \times 10^{6} 5 \mathrm{~T} 33$ tumor cells iv, received 500 cGy WBI 7 days after tumor cell inoculation, and were treated with checkpoint blocking antibodies (200 ug of each antibody ip) at the time points indicated in Figure 3A. Administration of anti-PD-L1 alone eliminated myeloma in $\sim 40 \%$ of mice (Figure $2 \mathrm{~B}-\mathrm{E}$ ), which is consistent with our previous results [39]. While treatment with anti-TIM-3 or anti-LAG-3 alone had no affect on survival (Figure 2B, C), co-administration of either antibody with anti-PD-L1 synergistically improved survival rates to greater than $80 \%$ (Figure $2 \mathrm{~B}, \mathrm{C}$ ). The combination of anti-TIM-3 with anti-LAG-3 failed to improve survival (Figure 2C). Therefore, PD-L1 blockade was necessary in order to see any survival benefit from blocking the two other checkpoints. Survival was also significantly improved by combining anti-PD-L1 with anti-CTLA4 (Figure 2D). Anti-CTLA4 alone also facilitated the elimination of myeloma in approximately $15 \%$ of animals. Since a blocking antibody to $2 \mathrm{~B} 4$ was not available, an antibody to the $2 \mathrm{~B} 4$ ligand, $\mathrm{CD} 48$, was used to block the 2B4/CD48 axis. As shown in Figure 3E, antiCD48 administered alone or with anti-PD-L1 failed to have any impact on the elimination of myeloma.

In order to test if survivors from the experiments in Figure 3B-D had developed anti-tumor memory, they were challenged with $1 \times 10^{6} 5 \mathrm{~T} 33$ tumor cells iv 100-110 days after the initial tumor cell inoculation and followed for tumor development. All survivors of the experiments in Figure 3B-D survived the 5T33 re-challenge, indicating that blocking the indicated combinations of checkpoint receptors does not compromise anti-tumor immune memory (Figure 3F).

\section{Combined checkpoint blockade increases the frequency of myeloma-reactive CD8 and CD4 T cells}

Since previous data from our laboratory demonstrated that the increased survival of myeloma-bearing mice treated with lymphodepleting WBI and anti-PD-L1 is T cell mediated [39], we set out to determine if combined checkpoint blockade increases numbers of functional tumor-reactive $\mathrm{T}$ cells. To do this, mice were treated according to the schedule in Figure 3A, but instead of 6 doses of blocking antibody, they received 3 doses on days 12, 14 and 19 following tumor cell injection. Twenty-one days after tumor cell injection, $\mathrm{T}$ cells were harvested from the spleens and bone marrow and CD4 and CD8 T cells were enriched by immunomagnetic cell sorting. Frequencies of tumorreactive IFN- $\gamma$-producing cells were then assessed in ELISPOT assays. CD8 T cells were stimulated with wild-type $5 \mathrm{~T} 33$ cells, while MHC class II-expressing 5T33 cells (engineered to express CIITA) were used to stimulate CD4 T cells. Both spleen and bone marrow-derived CD4 and CD8 $T$ cells showed a significant increase in tumor-specific IFN$\gamma$ producing cells when mice were treated with anti-PD-L1 in combination with anti-TIM-3, or anti-LAG-3 or antiCTLA4 as compared to anti-PD-L1 alone (Figure 4A).

To determine if there were differences in bulk cytokine production, splenic CD8 T cells were co-cultured with 5T33 tumor cells for 48 hours, supernatants were collected, 
A

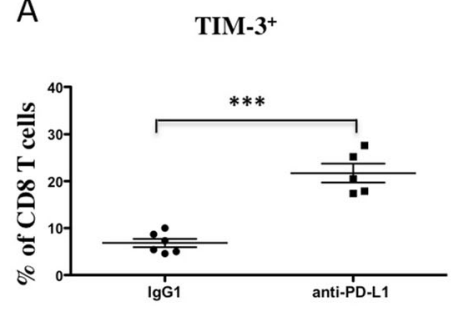

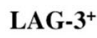

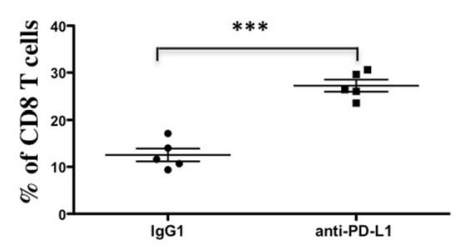

$2 \mathbf{B 4}^{+}$

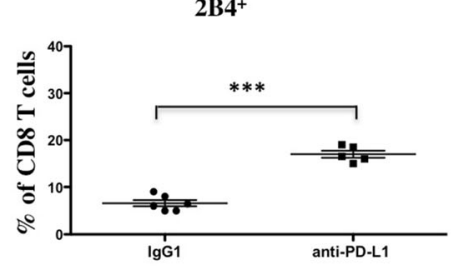

B
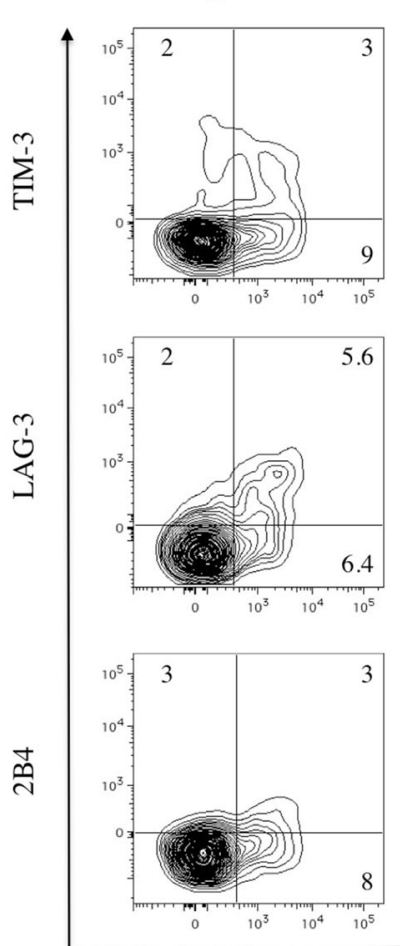

PD-1

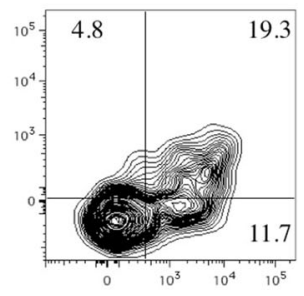

$\alpha-\mathrm{PD}-\mathrm{L} 1$
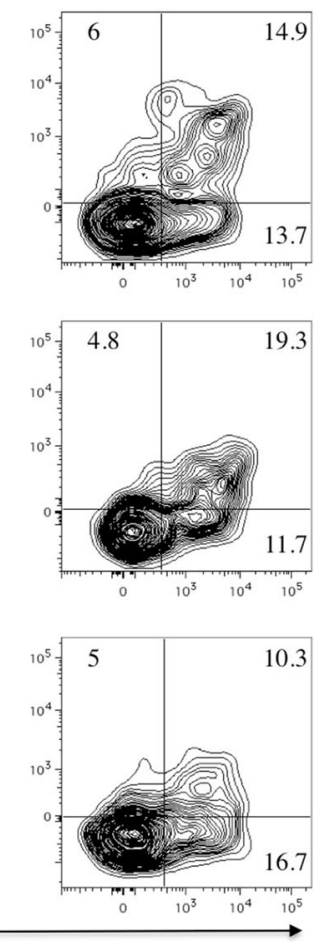

$-1$

Figure 2 Expression of immune checkpoint proteins are increased on T cells in mice treated with sublethal whole body irradiation and anti-PD-L1. Myeloma bearing KaLwRij mice were treated with 500 cGy whole body irradiation 7 days after tumor cell injection. Treatment with anti-PD-L1 or control lgG (200 $\mu \mathrm{g}$ ip) was initiated 5 days later and specifically given 12, 14, and 19 days after tumor injection. Mice were euthanized at day 21, splenocytes were harvested, and the CD8 T cells were analyzed by flow cytometry for immune checkpoint protein expression. (A) Frequency of $\mathrm{CD}^{+} \mathrm{TIM}^{-3^{+}}, \mathrm{CD}^{+} \mathrm{LAG}^{-} 3^{+}$and $\mathrm{CD} 8^{+} 2 \mathrm{~B} 4^{+}$cells in spleens of anti-PD-L1 treated mice as compared with spleens harvested from control antibody (lgG1) treated mice. ${ }^{* * *} \mathrm{p}<0.001$. (B) Expression of TIM-3 and PD-1, LAG-3 and PD-1 or $2 \mathrm{~B}_{4}$ and PD-1 on gated CD8 ${ }^{+} \mathrm{T}$ cells. Data shown are representative of more than four independent analyses.

and cytokine secretion was determined using a multiplex cytokine assay. Similar to results of the IFN- $\gamma$ ELISPOT assays, there was a significant increase in type 1 cytokines (IL-2, IFN- $\gamma$ and GM-CSF) produced by CD8 T cells harvested from mice that had received anti-PD-L1 in combination with anti-TIM-3, or anti-LAG-3 or anti-CTLA4 as compared to anti-PD-L1 alone (Figure 4B). Notably, CD8 $\mathrm{T}$ cells from mice treated with anti-PD-L1 in combination with anti-CTLA4 produced at least 2-fold higher concentrations of cytokines as compared to mice treated with anti-PD-L1 in combination with anti-TIM-3 or anti-LAG-3.

\section{Combined checkpoint blockade results in increased} expression of PD-1 on T cells, and ongoing PD-L1 blockade in vitro results in elevated numbers of IFN $-\nu$ producing cells There is data suggesting that expression of inhibitory receptors, including PD-1, correlates with T cell activation and/or differentiation rather than exhaustion [40]. Other investigators have also shown that the majority of vaccine- induced $\mathrm{CD}^{+}{ }^{+} \mathrm{T}$ cells upregulate PD-1 [41], and PD-1 has been found on clonally expanded tumor-reactive $\mathrm{CD}^{+} \mathrm{T}$ cells isolated from tumors [42]. Similarly, we showed that in mice with 5T33 myeloma, PD-1 expression was upregulated only on host $\mathrm{T}$ cells capable of recognizing tumor antigens, and not on non-tumor-specific ovalbuminreactive OT-1 T cells [39]. In sum, these data indicate that PD-1 is a marker of activated tumor-specific T cells in the cancer setting. Based on these observations, we hypothesized that combined immune checkpoint blockade after lymphodepleting WBI would result in increased percentages of $\mathrm{T}$ cells that express $\mathrm{PD}-1$, representing increased numbers of myeloma-reactive $\mathrm{T}$ cells. Mice were treated as shown in Figure 3A, except they received only the first 3 doses of antibody. CD8 T cells were harvested from the spleen and bone marrow 21 days after tumor injection and were analyzed for PD-1 expression. In support of our hypothesis, we observed significant increases in percentages of PD $-1^{+}$CD8 $\mathrm{T}$ cells in the spleens and bone 


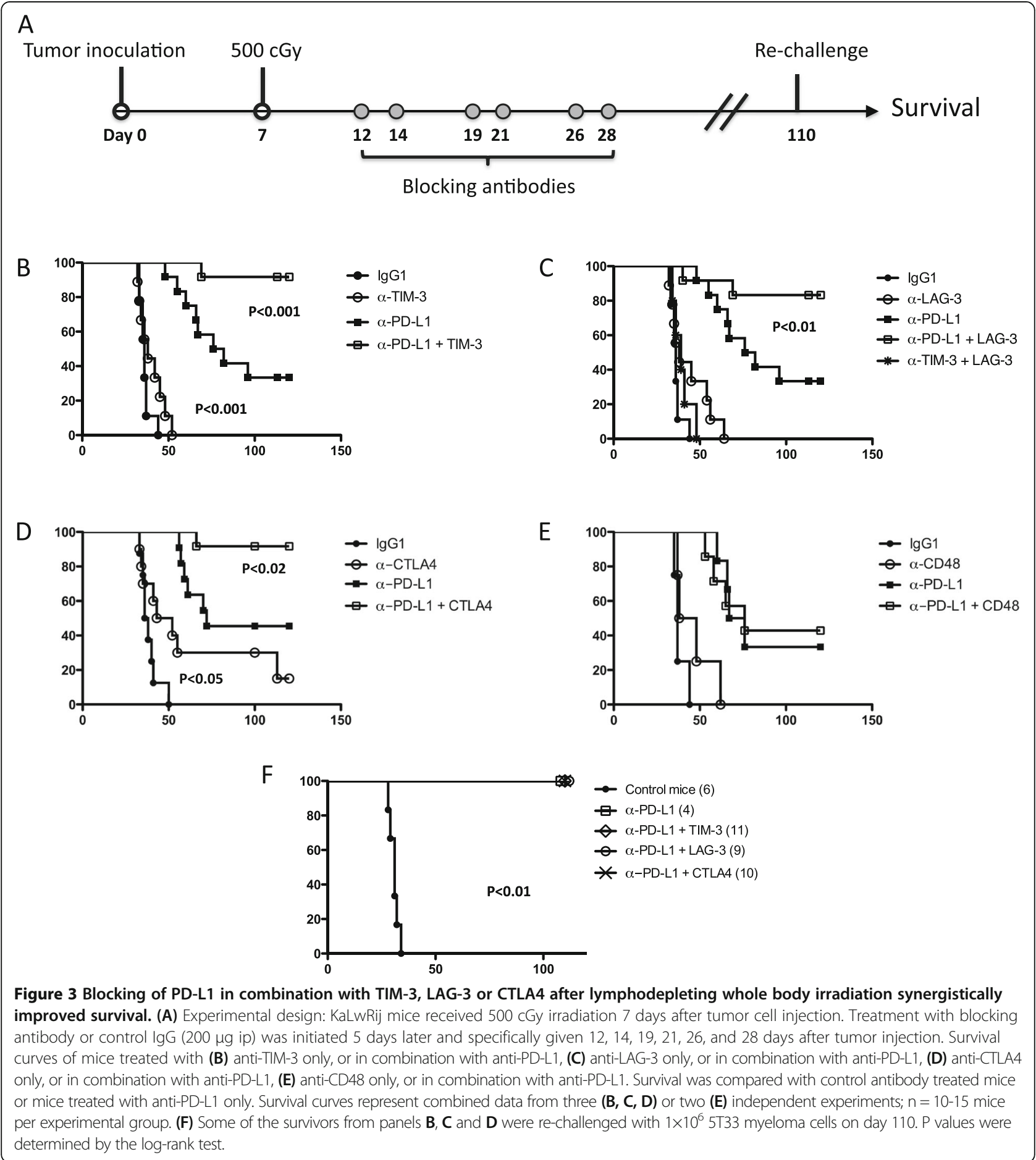

marrow of mice treated with anti-PD-L1 in combination with anti-TIM-3, anti-LAG-3 or anti-CTLA4 as compared to anti-PD-L1 alone (Figure 5A).

To explain the increased anti-myeloma immunity after WBI and checkpoint blockade, we have proposed the following model: (a) PD- $1^{+}$tumor-reactive CD8 T cells are rendered dysfunctional upon encounter with PD-L1 and other checkpoint ligands on the myeloma cells (5T33 expresses high levels of PD-L1) [39] or other cells in the microenvironment, (b) that the $\mathrm{PD}-1^{+}$cells are able to recover function after WBI due to the transient lymphopenic state through mechanisms yet to be identified, and (c) ongoing checkpoint blockade is required to maintain function of the re-activated T cells. To address 


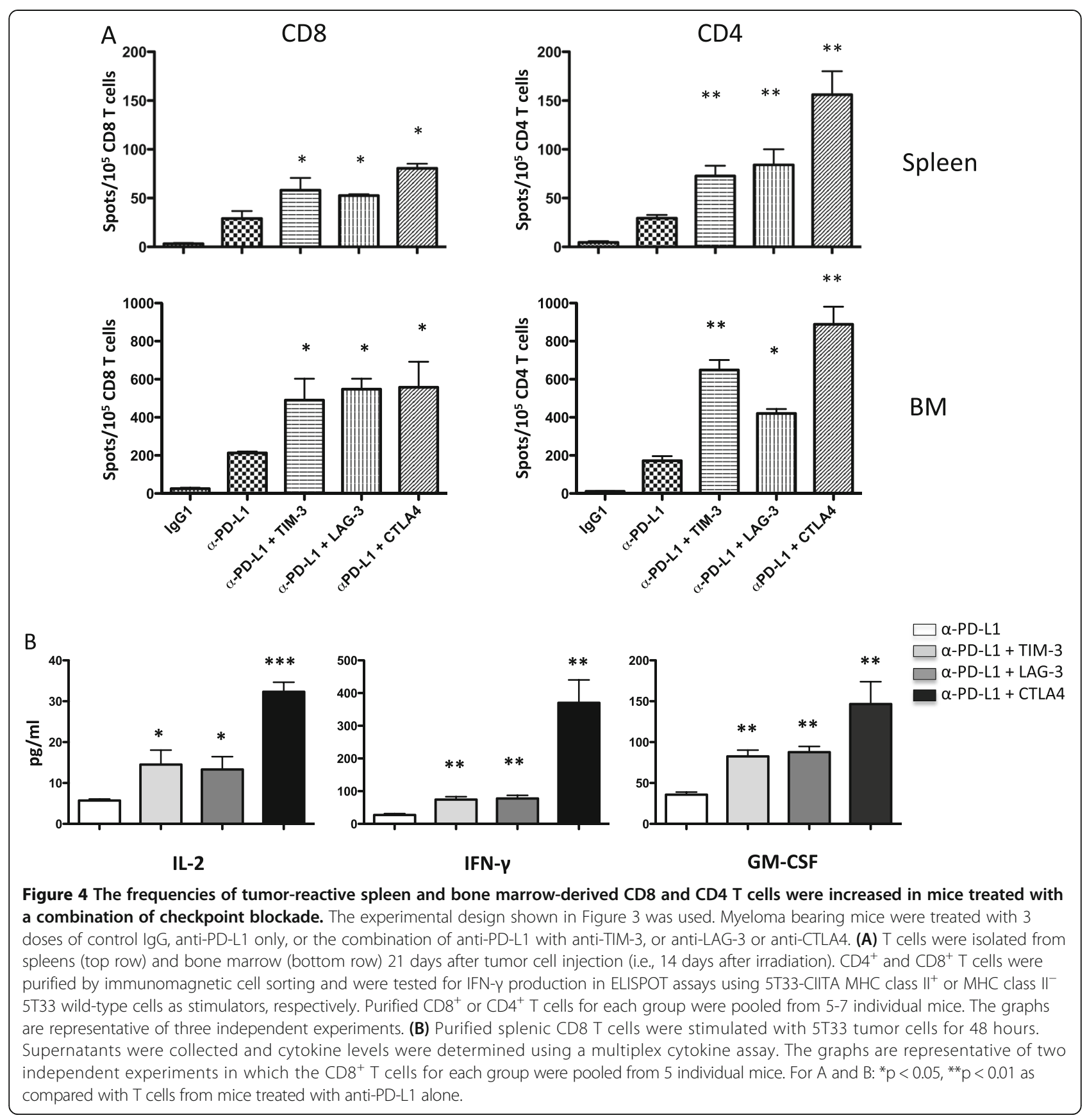

the last part of this model, we again performed IFN- $\gamma$ ELISPOT assays on CD8 $\mathrm{T}$ cells isolated from mice treated with 500 cGy WBI and combined checkpoint blockade, but anti-PD-L1 or control IgG1 antibody was also added in vitro to the 48-hour CD8 T cell/tumor cell co-cultures. PD-L1 blockade in vitro significantly increased the frequencies of IFN- $\gamma$-producing CD8 $\mathrm{T}$ cells from mice treated with anti-PD-L1 only or combinations of anti-PD-L1 and other checkpoint blocking antibodies (Figure 5B). These results highlight the importance of the PD-1/PD-L1 pathway in suppressing immunity to the 5T33 myeloma, and they support our model that ongoing checkpoint blockade is needed to maintain the function of activated tumor-specific CD8 cells long enough for them to eliminate the myeloma cells and generate memory.

\section{Spontaneous and tumor-specific production of Th1 and} Th2 cytokines is elevated from CD4 T cells of mice treated with anti-PD-L1 plus anti-CTLA4

CD4 T cells from mice treated with WBI and immune checkpoint blockade were also analyzed for cytokine 


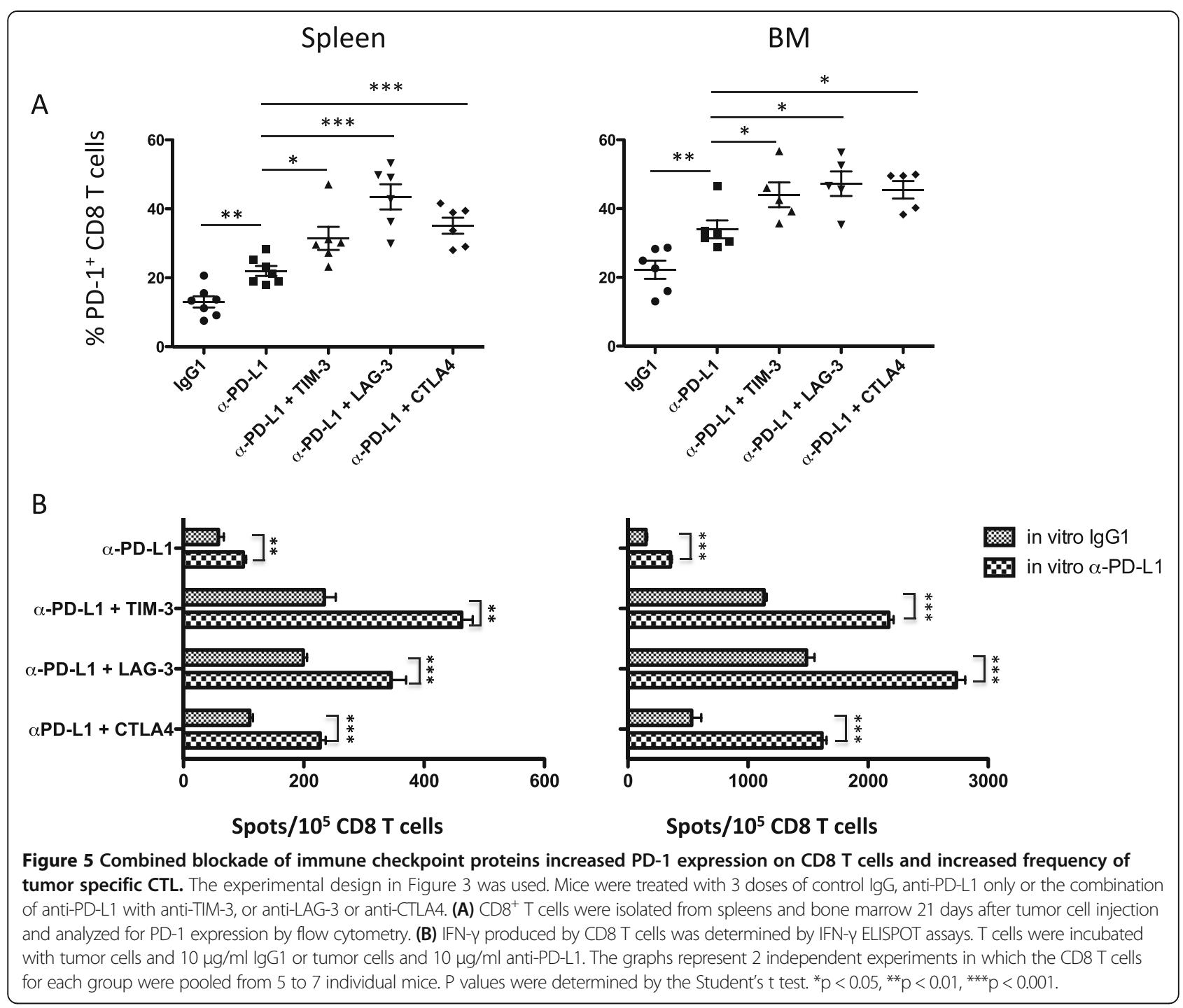

production in response to tumor cells in vitro. Mice were once again treated according to the schedule in Figure 3A, except they received three antibody doses instead of six. On day 21 after myeloma inoculation, CD4 $\mathrm{T}$ cells were harvested from the spleen and purified by immunomagnetic cell sorting. Cells were incubated with 5T33-CIITA tumor cells expressing MHC class II molecules for 48 hours followed by cytokine analysis in multiplex cytokine assays. Spontaneous cytokine release was analyzed by incubating CD4 T cells alone or with wild-type 5T33 cells. CD4 T cells harvested from mice treated with anti-PD-L1 plus anti-CTLA4 spontaneously released IFN- $\gamma$, as well as the Th2 cytokines IL-4 and IL-5 (Figure 6). Cytokine release was significantly increased when the $\mathrm{T}$ cells were incubated with 5T33CIITA MHC class $\mathrm{II}^{+}$tumor. CD4 T cells harvested from mice treated with anti-PD-L1 plus anti-LAG-3 or anti-TIM-3 also released IFN- $\gamma$ when stimulated with
5T33-CIITA cells, but there was no spontaneous or tumor-induced release of IFN- $\gamma$, IL-4 and IL-5.

\section{Discussion}

From our results to date, we propose a working model whereby low dose WBI generates a transient state of lymphopenia, which allows for the reactivation of myelomareactive $\mathrm{T}$ cells that have been rendered dysfunctional by checkpoint proteins. Checkpoint blockade then allows the re-activated $\mathrm{T}$ cells to remain functional and eliminate the myeloma. Lymphodepleting WBI and PD-L1 blockade failed in two solid tumors, but provided anti-tumor efficacy in other murine hematologic malignancy models, suggesting that hematologic malignancies may be more amenable to this treatment strategy [39]. The current study furthers the earlier work by demonstrating that myeloma experienced $\mathrm{T}$ cells upregulate expression of multiple checkpoint receptors including PD-1, LAG-3, 

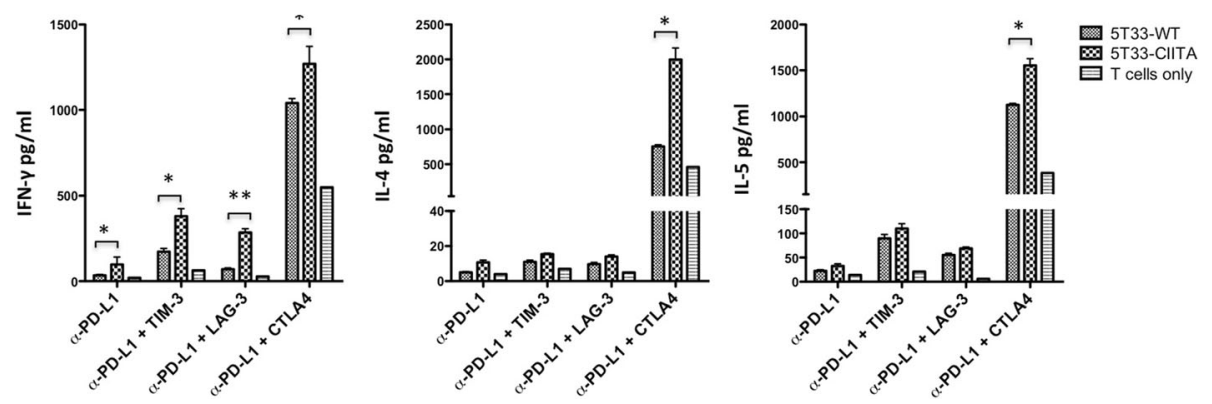

Figure 6 There is spontaneous release of Th1 and Th2 cytokines from splenic CD4 T cells harvested from mice treated with anti-PD-L1 and anti-CTLA4. The experimental design shown in Figure 3 was used. Mice were treated with anti-PD-L1, or the combination of anti-PD-L1 with anti-TIM-3, or anti-LAG-3 or anti-CTLA4. T cells were isolated from spleens 21 days after tumor cell injection (14 days after irradiation). CD4 T cells were purified by immunomagnetic cell sorting, then stimulated with MHC class II- 5 T33 wild-type cells, 5T33-CIITA MHC class $\|^{+}$cells or T cells only for 48 hours. Supernatants were collected and cytokine levels from were determined using a multiplex cytokine assay. The graphs are representative of two independent experiments in which the $\mathrm{CD}^{+} \mathrm{T}$ cells for each group were pooled from 5 individual mice. $p<0.05,{ }^{* *} p<0.01$.

TIM-3 and 2B4. Furthermore, treatment of myelomabearing mice with lymphodepletive WBI and dual checkpoint blockade induced a synergistic anti-myeloma effect, and this enhanced elimination of myeloma was associated with increased numbers of IFN- $\gamma$-producing tumorreactive $\mathrm{T}$ cells and elevated cytokine production by $\mathrm{T}$ cells in response to tumor antigens.

Multiple immune checkpoints have been previously shown to be upregulated on T cells in several murine solid tumor models, and targeting more than one pathway has demonstrated increased anti-tumor efficacy [19,21,22,43-52]. However, there is a paucity of literature regarding expression of immune checkpoints on T cells in hematologic malignancies or the effect of targeting more than one checkpoint as therapy for these cancers [22]. Clinically, PD-1 and CTLA4 have been simultaneously targeted for the treatment of melanoma, and anti-tumor activity appears to be more robust than targeting each pathway alone [15]. Notably, autoimmune manifestations with this combination did not appear to be significantly worsened. In our studies, blockade of the PD-1/PD-L1 pathway appears to provide an activation threshold for myeloma-reactive $\mathrm{T}$ cells that allows blockade of other checkpoints to provide synergistic anti-myeloma responses. Interestingly, blockade of LAG-3, TIM-3 or CTLA4 alone had only modest or no effect on elimination of myeloma after WBI. How inhibitory signals transmitted through TIM-3 and LAG-3 synergize with those transmitted through PD-1 is unknown. It could be that there is constitutive inhibitory signaling through TIM- 3 and LAG-3 by the presence of pleotropic ligands (Additional file 2: Figure S2). The blocking of these constitutive inhibitory signals may have an observable anti-tumor effect only when dominant inhibitory signaling through PD-1 is blocked. In contrast, when combined with PD-L1 blockade, potent anti-myeloma effects were observed when each of these pathways was targeted (Figure 3).
Treatment with WBI and anti-PD-L1 resulted in increased expression of PD-1 as well as LAG-3, TIM-3 and 2B4 (Figure 2). Furthermore, blockade of PD-L1 with other immune checkpoints (TIM-3, LAG-3 and CTLA4) drove up PD-1 expression on T cells even further (Figure 5A). This result is surprising, as the expression of checkpoint receptors on $\mathrm{T}$ cells have been regarded as markers of dysfunction. In settings of chronic antigen exposure, such as cancer, expression of checkpoint receptors such as PD-1, CTLA4, TIM-3, LAG-3, and 2B4 have been associated with dysfunctional $\mathrm{T}$ cells, often termed exhausted or tolerized [53-57]. However, there are recent reports that $\mathrm{PD}-1^{+} \mathrm{T}$ cells may not be functionally impaired, but instead represent $\mathrm{T}$ cells that have been activated. In healthy adults, $\mathrm{PD}-1^{+}$peripheral $\mathrm{CD} 8 \mathrm{~T}$ cells were shown to be effector memory cells and not exhausted T cells [58]. In support of this data, Baitsch et al. found that the majority of human effector memory $\mathrm{T}$ cells co-expressed PD-1, CTLA4, KLRG-1, 2B4, LAG-3 or CD160 [59]. Also, in human CD8 T cells, an increase in co-expression of inhibitory receptors such as PD-1, TIM-3, 2B4, CD160 and KLRG1 correlated with T cell differentiation or activation status [40]. In support of these findings we found that sorted $\mathrm{PD}-1^{+}$tumorexperienced $\mathrm{CD} 8 \mathrm{~T}$ cells secrete IFN- $\gamma$ when in vitro incubated with myeloma cells and anti-PD-L1 blocking antibody (unpublished data). The mechanism(s) by which checkpoint receptors are regulated by blocking antibodies and how this induces $\mathrm{T}$ cell activation is currently unknown. In order to dissect the mechanism(s) involved, further investigation of the myeloma-reactive $\mathrm{T}$ cells is required. Since the tumor antigens in the 5 T33 tumor model are unknown, we have genetically modified 5T33 cells to express a model antigen, SIINFEKL ovalbumin peptide, so that we can detect and isolate 'tumor-specific' cells using a MHC/SIINFEKL pentamer 
reagent. Once myeloma-specific CD8 T cells are identified and isolated, the mechanism of how checkpoint blockade regulates checkpoint expression can be interrogated.

Currently, there is no reliable way to predict which patients are going to benefit from checkpoint blockade. However, our data may provide clues as to which combination of checkpoint molecules to block based on the expression pattern of checkpoint receptors on $\mathrm{T}$ cells. We observed increased expression of TIM-3, LAG-3, CTLA4, and 2B4 on both CD8 and CD4 T cells in myeloma-bearing mice, and anti-myeloma synergy occurred when the PD-1/PD-L1 axis was blocked in combination with blocking TIM-3, LAG-3, or CTLA4. Despite upregulation of $2 \mathrm{~B} 4$ on $\mathrm{T}$ cells with increasing myeloma burden, which has also been observed on CD8 and CD4 T cells in a mouse pancreatic cancer model [60], blockade of PD-L1 plus the ligand for $2 \mathrm{~B} 4, \mathrm{CD} 48$, did not provide any additional benefits over PD-L1 blockade alone. It is possible that the CD48-specific antibody used in this study did not block the $2 \mathrm{~B} 4 / \mathrm{CD} 48$ receptor axis, although the antibody clone used has been reported to block the pathway [61]. Another possible reason for the lack of synergy stems from a report that $2 \mathrm{~B} 4$ has both $\mathrm{T}$ cell proliferative and inhibitory effects [32]. Recently, CD48 was found to be expressed on more than $90 \%$ of plasma cells from myeloma patients at higher levels than those observed on normal lymphocytes [62], although it is unknown whether this elevated expression could have a negative impact on $\mathrm{T}$ cell reactivity. This will need to be examined more closely in future studies.

As noted earlier, we observed anti-myeloma synergy when mice were treated with anti-PD-L1 and anti-CTLA4 blocking antibodies. In clinical trials, treatment with antiCTLA4 has been associated with multiple immunerelated adverse events including colitis, hepatitis, and thyroiditis [63]. Treatment of patients with antibodies targeting the PD-1/PD-L1 pathway has also resulted in some toxicities, although they have typically been less severe than those observed with CTLA4 antibodies [64]. We did not observe weight loss or any gross toxicities in mice treated with anti-PD-L1 and anti-CTLA4, despite the fact that this checkpoint blockade combination produced significantly more Th1 and Th2 cytokines than anti-PD-L1 in combination with anti-TIM-3 or anti-LAG3 (Figures 4B and 6). Notably, the frequencies of IFN- $\gamma$ producing tumor-reactive $\mathrm{CD} 8 \mathrm{~T}$ cells from anti-PD-L1/ CTLA4 treated mice were similar to those treated with the anti-PD-L1/LAG-3 and anti-PD-L1/TIM-3 combinations (Figures 4A and 5B). However, since the bulk production of IFN- $\gamma$ was increased (Figure 4B), it appears that tumor-reactive $\mathrm{CD} 8 \mathrm{~T}$ cells in anti-PD-L1/CTLA4 treated mice produce more cytokines on a per cell basis. Similar to this observation, combined immunotherapy using OX40 stimulation with CTLA4 inhibition enhanced Th1 and Th2 cytokine production by effector T cells [65].
$\mathrm{T}$ regulatory function was not inhibited by this approach. In our study, there were no differences in the percentages of $\mathrm{Gr}-1^{+} \mathrm{CD} 11 \mathrm{~b}^{+}$myeloid cells or regulatory $\mathrm{T}$ cells in the spleens of myeloma-bearing mice treated with anti-PD-L1 plus anti-CTLA4 as compared to anti-PD-L1 plus other checkpoint antibodies (Additional file 3: Figure S3). These data suggest that these cells may not be involved with regulating $\mathrm{T}$ cell cytokine production. However, confirmatory functional studies remain to be done. It is possible that anti-tumor synergy produced by anti-PD-L1 in combination with anti-LAG-3 or anti-TIM3 antibodies may be a less toxic alternative to anti-PD-L1 in combination with anti-CTLA4 antibodies.

Finally, it is important to note that we previously reported treatment with a lymphodepleting dose of 500 cGy WBI prior to treatment with anti-PD-L1 was a prerequisite for generating effective anti-myeloma immunity [39]. Therefore, in the current study we also treated mice with 500 cGy WBI prior to administering checkpoint-blocking antibodies. The mechanisms of how WBI sensitizes the immune system to produce effective checkpoint blockade has yet to be determined. Multiple immune factors may be important such as providing a lymphopenic environment to induce homeostatic expansion of tumor-reactive $\mathrm{T}$ cells.

\section{Conclusions}

In summary, we show that combined immune checkpoint blockade provides a synergistic anti-myeloma effect in mice treated with low dose, lymphodepleting WBI. The anti-myeloma effect correlates with activation of $\mathrm{T}$ cells, which appears to be maintained by checkpoint blockade. The importance of sustaining immune checkpoint blockade until tumor cells are eliminated is highlighted by the positive impact addition of anti-PD-L1 had on IFN- $\gamma$ producing $\mathrm{T}$ cells when added to $\mathrm{T}$ cell/myeloma cell co-cultures in ELISPOT assays (Figure 5B). Increased $\mathrm{T}$ cell expression of checkpoint molecules following checkpoint blockade suggests that expression of these molecules is an indicator of $\mathrm{T}$ cell activation, rather than a state of irreversible exhaustion. Given our antimyeloma results using checkpoint blockade, continued study of checkpoint blockade in other hematologic malignancies is warranted. In future studies, it will be interesting to see if targeting more than two checkpoint pathways simultaneously in myeloma and other hematologic malignancies can further improve anti-tumor immunity without generating unacceptable autoimmunity. Understanding the mechanisms of tumor cell elimination induced by combined checkpoint blockade and low dose WBI, and determining if other lymphodepleting strategies can be used, such as lymphodepleting drugs or low doses of $\mathrm{T}$ cell depleting antibodies, will help to expand the translational applications of this approach. Finally, this therapeutic 
approach could serve as a platform for other immune therapies, including $\mathrm{T}$ cell adoptive transfer.

\section{Methods \\ Mice}

C57BL/KaLwRij (KaLwRij) and (KaLwRij $\times$ C57BL/ 6.SJL)F1 mice were bred and housed in the Medical College of Wisconsin Biomedical Resource Center, which is an American Association for the Accreditation of Laboratory Animal Care (AAALAC)-accredited facility. All animal work was reviewed and approved by the Medical College of Wisconsin Institutional Animal Care and Use Committee.

\section{Tumor cells}

The 5T33 murine myeloma cell line was derived from a myeloma that spontaneously arose in a C57BL/KaLwRij mouse [40]. 5T33 cells were transduced to express emerald green fluorescent protein (5T33-GFP), as previously described [39]. MHC class $\mathrm{II}^{+} 5 \mathrm{~T} 33$ cells (designated 5T33-CIITA) were derived by transducing 5T33 cells with a lentiviral expression vector (PLVX-N1; ClonTech, Mountain View, CA) encoding the MHC class II transactivator (CIITA) gene. Mice were inoculated with $2 \times 10^{6}$ 5 T33 or 5T33-GFP cells intravenously (iv). Myelomabearing mice were considered as moribund and euthanized when they developed paraparesis or paraplegia. Occasionally, 5T33-injected mice developed tumor masses or other related lesions and were euthanized when the size of the mass or lesion exceeded $250 \mathrm{~mm}^{2}$. Other symptoms of advanced tumor burden included splenomegaly, hepatomegaly, or neurologic impairment.

\section{Antibodies and flow cytometry}

The following monoclonal anti-mouse antibodies and flow cytometry reagents were obtained from eBioscience (San Diego, CA): anti-CD4 (GK1.5), anti-CD8 (53-6.7), anti-PD-1 (J43), anti-TIM-1 (RMT1-4), anti-TIM-3 (RMT323), anti-LAG-3 (C987W), anti-2B4 (244F4), anti-CTLA4 (UC10-4F10-11), anti-BTLA (8F4), anti-PD-L1 (MIH5), anti-galectin-9 (108A2), anti-I-A ${ }^{\mathrm{b}}$ (AF6-120.1), anti-CD80 (16-10A1), anti-H2Kb (AF6-88.5.5.3), anti-CD11b (M170), anti-CD11c (N418), anti-F4/80 (BM8), anti-Gr-1 (RB6$8 \mathrm{C} 5$ ), anti-Foxp3 (FJK-16 s) and propidium iodide staining solution. The following antibodies and reagents were obtained from Biolegend (San Diego, CA): anti-CD8 (53-6.7), anti-PD-1 (J43), and anti-TIM-3 (B8.2C12), anti-CD19(GD5). Flow cytometry was done on a BD Biosciences (Franklin Lakes, NJ) LSRII flow cytometer, and resulting data analyzed using FlowJo software (Tree Star, Inc.).

\section{Antibody treatment of myeloma-bearing mice} C57BL/KaLwRij or (KaLwRij $\times$ C57BL/6.SJL)F1 mice were injected with $2 \times 10^{6} 5 \mathrm{~T} 33$ cells iv. The myeloma bearing mice were irradiated with 500 cGy whole body irradiation (WBI) using a cesium irradiator 7 days after myeloma inoculation. Antibody treatment was initiated 5 days after WBI and administered on days 12, 14, 19, 21, 26, and 28 after myeloma inoculation. 5T33 tumor-bearing mice were treated with anti-PD-L1 (clone 10F.9G2; BioXCell), anti-LAG-3 (clone C9B7W), anti-TIM-3 (clone 5D12; CoStim/Novartis), anti-CTLA4 (clone 9H10; BioXCell), or anti-CD48 (clone HM48-1; BioXCell) monoclonal antibodies at the indicated time points. Some mice received a combination of anti-PD-L1 plus anti-LAG-3, anti-TIM-3 or anti-CTLA4. Rat immunoglobulin G (IgG) was administered as control antibody. All antibodies were given at a dose of $200 \mu \mathrm{g}$ by intraperitoneal (ip) injection. Myelomabearing mice were considered as moribund and euthanized when they developed hind-leg paralysis or other defined endpoints. Mice that survived the initial treatment were re-challenged with $1 \times 10^{6} 5$ T 33 tumor cells 100-110 days after the first inoculation.

\section{Interferon-gamma (IFN- - ) ELISPOT assays}

To assess for presence of tumor-reactive, interferongamma (IFN- $\gamma$ )-secreting CD8 or CD4 T cells, T cells were harvested from the spleen and bone marrow, and isolated by immunomagnetic cell sorting as previously described [35]. IFN-gamma enzyme-linked immunosorbent spot (ELISPOT) assays were done using mouse IFN- $\gamma$ ELISPOT kits from BD Biosciences, as described previously [39]. The ELISPOT data was quantified using a Cellular Technology Limited (CTL) ImmunoSpot Analyzer (CTL Analyzers, Cleveland, OH).

\section{Bio-plex cytokine assays}

CD4 and CD8 T cells from antibody treated myelomabearing mice were cultured in media alone or in the presence of 5T33 wild type or 5T33-CIITA tumor cells. Culture supernatants were harvested after 48 hours and stored at $-80^{\circ} \mathrm{C}$. Thawed supernatants were then analyzed using a murine multiplex cytokine kit (Bio-Rad, Hercules, CA) to detect IL-2, IL-4, IL-5, IL-10, IL-12p70, granulocyte-macrophage colony stimulating factor (GMCSF), tumor necrosis factor-alpha (TNF- $\alpha$ ), and IFN- $\gamma$. Cytokines were quantified using a Bio-Plex protein 200 array reader, and data was automatically processed and analyzed by the Bio-Plex Manager Software 4.1 using standard curves generated from recombinant cytokine standards. All samples were assayed in duplicate.

\section{Statistics}

Survival curves were compared using the log-rank (Mantel Cox) test. Other experiments were compared using the Student's $\mathrm{t}$ test. $\mathrm{P}$ values $<0.05$ were considered as significant. Statistical analysis was done using Prism version 5.0a software (GraphPad Software, La Jolla, CA). 


\section{Additional files}

Additional file 1: Figure S1. Expression of immune checkpoint proteins on T cells in spleens of myeloma bearing mice over time. KaLwRij mice were inoculated with $2 \times 10^{6} 5$ T33-GFP cells iv. Myeloma bearing mice were euthanized between days 7 and 28 and when moribund at days $29-40$ after myeloma injection. Spleens were harvested and $\mathrm{CD}^{+}$and $\mathrm{CD}^{+} \mathrm{T}$ cells were analyzed for immune checkpoint protein expression over time by flow cytometry. T cells harvested from naïve nonmyeloma bearing mice were analyzed as controls. Immune checkpoint protein percentages were calculated based on isotype controls. ${ }^{*} p<0.05$, ${ }^{* *} p<0.01$, ${ }^{* * *} p<0.001$ as compared to $T$ cells from naïve non-myeloma bearing mice

Additional file 2: Figure S2. Membrane expression of immune checkpoint protein ligands on myeloma and splenocytes. (A) PD-L1, galectin-9, MHC class II (I-A $)$ and CD80 expression on 5 T33 tumor cells (solid line), and on 5 T33 tumor cells irradiated in vitro with 500 cGy (dashed line). Isotype controls are shaded in gray. (B) Expression of PD-L1 galectin-9, MHC class II (I-A $)$ and CD80 on B cells, macrophages, dendritic cells (DC) and monocytes in the spleens of moribund myeloma-bearing mice. Fluorescence minus one (FMO) controls are shaded in gray.

Additional file 3: Figure S3. Percentages of myeloid and regulatory $T$ cells in the spleens of mice treated with combinations of blocking antibodies to immune checkpoint proteins. Mice were treated as shown in Figure 3A. Myeloma bearing mice were treated with three doses of control lgG, anti-PD-L only, or a combination of anti-PD-L1 with anti-TIM-3, anti-LAG-3 or anti-CTLA4. At day 21 after myeloma inoculation, spleens were harvested and the percentages of Foxp $3^{+} \mathrm{CD} 4^{+}$regulatory $T$ cells and $\mathrm{Gr}-1^{+} \mathrm{CD} 11 \mathrm{~b}^{+}$myeloid cells were analyzed by flow cytometry.

\section{Abbreviations}

CTLA4: Cytotoxic T-lymphocyte antigen-4; CIITA: MHC class II transactivator; GFP: Green fluorescent protein; GM-CSF: Granulocyte-macrophage colony-stimulating factor; IFN: Interferon; LAG-3: Lymphocyte activating gene-3; PD-1: Programmed death receptor-1; PD-L1: Programmed death receptor ligand-1; TIL: Tumor-infiltrating Iymphocyte; TIM-3: T cell immunoglobulin and mucin domain-3; WBI: Whole body irradiation.

\section{Competing interests}

WJ, JG, JW, DT, LM and BJ declare that they have no competing interests. CSP is an employee of Novartis.

\section{Authors' contributions}

WJ designed and performed all experiments and wrote the manuscript. BJ designed the overall study and wrote the manuscript. JG assisted with the study design, data interpretation, and wrote the manuscript. JW, DT and LM assisted and performed experiments, and participated in editing of the manuscript. CSP assisted with the study design, data interpretation, and editing of the manuscript. All authors read and approved the final manuscript.

\section{Acknowledgements}

The authors would like to thank Dr. Ana Anderson and Dr. Vijay Kuchroo, Harvard Medical School, for their contributions in generating the 5D12 anti-TIM-3 monoclonal antibody. This work was supported by the Midwest Athletes against Childhood Cancer Fund and a Senior Research Grant from the Multiple Myeloma Research Foundation (to BJ).

\section{Author details}

${ }^{1}$ Division of Hematology/Oncology/Transplant, Department of Pediatrics, Medical College of Wisconsin, Milwaukee, WI 53226, USA. ${ }^{2}$ Novartis Institutes for BioMedical Research, Inc., Cambridge, MA 02139, USA.

\section{Received: 26 August 2014 Accepted: 1 December 2014}

\section{References}

1. Takahashi T, Tagami T, Yamazaki S, Uede T, Shimizu J, Sakaguchi N, Mak TW Sakaguchi S: Immunologic self-tolerance maintained by CD25(+)CD4(+) regulatory $T$ cells constitutively expressing cytotoxic $T$ lymphocyteassociated antigen 4. J Exp Med 2000, 192(2):303-310.
2. Walunas $\mathrm{TL}$, Bluestone $\mathrm{JA}$ : CTLA-4 regulates tolerance induction and $\mathrm{T}$ cell differentiation in vivo. J Immunol 1998, 160:3855.

3. Waterhouse $P$, Penninger JM, Timms E, Wakeham A, Shahinian A, Lee KP, Thompson CB, Griesser H, Mak TW: Lymphoproliferative disorders with early lethality in mice deficient in Ctla-4. Science 1995, 270:985.

4. Simpson TR, Li F, Montalvo-Ortiz W, Sepulveda MA, Bergerhoff K, Arce F, Roddie C, Henry JY, Yagita H, Wolchok JD, Peggs KS, Ravetch JV, Allison JP, Quezada SA: Fc-dependent depletion of tumor-infiltrating regulatory $T$ cells co-defines the efficacy of anti-CTLA-4 therapy against melanoma. J Exp Med 2013, 210(9):1695-1710.

5. Peggs KS, Quezada SA, Chambers CA, Korman AJ, Allison JP: Blockade of CTLA-4 on both effector and regulatory $T$ cell compartments contributes to the antitumor activity of anti-CTLA-4 antibodies. J Exp Med 2009, 206(8):1717-1725

6. Hodi FS, O'Day SJ, McDermott DF, Weber RW, Sosman JA, Haanen JB, Gonzalez R, Robert C, Schadendorf D, Hassel JC, Akerley W, van den Eertwegh AJM, Lutzky J, Lorigan P, Vaubel JM, Linette GP, Hogg D, Ottensmeier CH, Lebbé C, Peschel C, Quirt I, Clark JI, Wolchok JD, Weber JS, Tian J, Yellin MJ, Nichol GM, Hoos A, Urba WJ: Improved survival with ipilimumab in patients with metastatic melanoma. N Engl J Med 2010, 363(8):711-723.

7. Greenwald RJ, Freeman GJ, Sharpe AH: The B7 family revisited. Annu Rev Immunol 2005, 23:515-548.

8. Seliger B, Marincola FM, Ferrone S, Abken H: The complex role of B7 molecules in tumor immunology. Trends Mol Med 2008, 14(12):550-559.

9. Zou W, Chen L: Inhibitory B7-family molecules in the tumour microenvironment Nat Rev Immunol 2008, 8(6):467-477.

10. Nomi T, Sho M, Akahori T, Hamada K, Kubo A, Kanehiro H, Nakamura S, Enomoto K, Yagita H, Azuma M, Nakajima Y: Clinical significance and therapeutic potential of the programmed death-1 ligand/programmed death-1 pathway in human pancreatic cancer. Clin Cancer Res 2007, 13(7):2151-2157.

11. Peng W, Liu C, Xu C, Lou Y, Chen J, Yang Y, Yagita H, Overwijk WW, Lizée G, Radvanyi L, Hwu P: PD-1 Blockade Enhances T-cell Migration to Tumors by Elevating IFN- $\gamma$ Inducible Chemokines. Cancer Res 2012 72(20):5209-5218

12. Iwai Y, Terawaki S, Honjo T: PD-1 blockade inhibits hematogenous spread of poorly immunogenic tumor cells by enhanced recruitment of effector T cells. Int Immunol 2005, 17(2):133-144.

13. Lipson EJ, Sharfman WH, Drake CG, Wollner I, Taube JM, Anders RA, Xu H, Yao S, Pons A, Chen L, Pardoll DM, Brahmer JR, Topalian SL: Durable cancer regression off-treatment and effective reinduction therapy with an anti-PD-1 antibody. Clin Cancer Res 2013, 19(2):462-468.

14. Topalian SL, Hodi FS, Brahmer JR, Gettinger SN, Smith DC, McDermott DF, Powderly JD, Carvajal RD, Sosman JA, Atkins MB, Leming PD, Spigel DR, Antonia SJ, Horn L, Drake CG, Pardoll DM, Chen L, Sharfman WH, Anders RA, Taube JM, McMiller TL, Xu H, Korman AJ, Jure-Kunkel M, Agrawal S, McDonald D, Kollia GD, Gupta A, Wigginton JM, Sznol M: Safety, Activity, and Immune Correlates of Anti-PD-1 Antibody in Cancer. N Engl J Med 2012, 366(26):2455-2465.

15. Wolchok JD, Kluger H, Callahan MK, Postow MA, Rizvi NA, Lesokhin AM, Segal NH, Ariyan CE, Gordon R-A, Reed K, Burke MM, Caldwell A, Kronenberg SA, Agunwamba BU, Zhang X, Lowy I, Inzunza HD, Feely W, Horak CE, Hong Q, Korman AJ, Wigginton JM, Gupta A, Sznol M: Nivolumab plus ipilimumab in advanced melanoma. N Engl J Med 2013, 369(2):122-133.

16. Xu F, Liu J, Liu D, Liu B, Wang M, Hu Z, Du X, Tang L, He F: LSECtin expressed on melanoma cells promotes tumor progression by inhibiting antitumor T-cell responses. Cancer Res 2014, 74(13):3418-3428.

17. Bettini M, Szymczak-Workman AL, Forbes K, Castellaw AH, Selby M, Pan X, Drake CG, Korman AJ, Vignali DAA: Cutting edge: accelerated autoimmune diabetes in the absence of LAG-3. J Immuno/ 2011, 187(7):3493-3498.

18. Matsuzaki J, Gnjatic S, Mhawech-Fauceglia P, Beck A, Miller A, Tsuji T, Eppolito C, Qian F, Lele S, Shrikant P, Old LJ, Odunsi K: Tumor-infiltrating NY-ESO-1-specific CD8+ T cells are negatively regulated by LAG-3 and PD-1 in human ovarian cancer. Proc Natl Acad Sci U S A 2010, 107(17):7875-7880.

19. Woo S-R, Turnis ME, Goldberg MV, Bankoti J, Selby M, Nirschl CJ, Bettini ML, Gravano DM, Vogel P, Liu CL, Tangsombatvisit S, Grosso JF, Netto G, Smeltzer MP, Chaux A, Utz PJ, Workman CJ, Pardoll DM, Korman AJ, Drake CG, Vignali DAA: Immune inhibitory molecules LAG-3 and PD-1 synergistically regulate $\mathrm{T}$-cell function to promote tumoral immune escape. Cancer Res 2012, 72(4):917-927. 
20. Curtiss ML, Gorman JV, Businga TR, Traver G, Singh M, Meyerholz DK, Kline JN, Murphy AJ, Valenzuela DM, Colgan JD, Rothman PB, Cassel SL: Tim-1 regulates Th2 responses in an airway hypersensitivity model. Eur J Immunol 2012, 42(3):651-661.

21. Sakuishi K, Apetoh L, Sullivan JM, Blazar BR, Kuchroo VK, Anderson AC: Targeting TIM-3 and PD-1 pathways to reverse T cell exhaustion and restore anti-tumor immunity. J Exp Med 2010, 207(10):2187-2194.

22. Zhou Q, Munger ME, Veenstra RG, Weigel BJ, Hirashima M, Munn DH, Murphy WJ, Azuma M, Anderson AC, Kuchroo VK, Blazar BR: Co-expression of TIM-3 and PD-1 identifies a CD8+ T-cell exhaustion phenotype in mice with disseminated acute myelogenous leukemia. Blood 2011, 117(17):4501-4510.

23. Heusschen R, Griffioen AW, Thijssen VL: Galectin-9 in tumor biology: a jack of multiple trades. Biochim Biophys Acta 2013, 1836(1):177-185.

24. Fourcade J, Sun Z, Benallaoua M, Guillaume P, Luescher IF, Sander C, Kirkwood JM, Kuchroo V, Zarour HM: Upregulation of TIM-3 and PD-1 expression is associated with tumor antigen-specific CD8+ T cell dysfunction in melanoma patients. J Exp Med 2010, 207(10):2175-2186

25. Gao Q, Wang X-Y, Qiu S-J, Yamato I, Sho M, Nakajima Y, Zhou J, Li B-Z, Shi Y-H, Xiao Y-S, XU Y, Fan J: Overexpression of PD-L1 significantly associates with tumor aggressiveness and postoperative recurrence in human hepatocellular carcinoma. Clin Cancer Res 2009, 15(3):971-979.

26. Yang Z-Z, Grote DM, Ziesmer SC, Niki T, Hirashima M, Novak AJ, Witzig TE, Ansell SM: IL-12 upregulates TIM-3 expression and induces T cell exhaustion in patients with follicular B cell non-Hodgkin lymphoma. J Clin Invest 2012, 122(4):1271-1282.

27. Anderson AC: TIM-3: an emerging target in the cancer immunotherapy landscape. Cancer Immunol Res 2014, 2(5):393-398.

28. Anderson AC, Anderson DE, Bregoli L, Hastings WD, Kassam N, Lei C, Chandwaskar R, Karman J, Su EW, Hirashima M, Bruce JN, Kane LP, Kuchroo VK, Hafler DA: Promotion of tissue inflammation by the immune receptor TIM-3 expressed on innate immune cells. Science 2007, 318(5853):1141-1143.

29. da Silva IP, Gallois A, Jimenez-Baranda S, Khan S, Anderson AC, Kuchroo VK, Osman I, Bhardwaj N: Reversal of NK-cell exhaustion in advanced melanoma by TIM-3 blockade. Cancer Immunol Res 2014, 2(5):410-422.

30. Ngiow SF, von Scheidt B, Akiba H, Yagita H, Teng MWL, Smyth MJ: Anti-TIM3 antibody promotes T cell IFN- $\gamma$-mediated antitumor immunity and suppresses established tumors. Cancer Res 2011, 71(10):3540-3551.

31. Kambayashi T, Assarsson E, Chambers BJ, Ljunggren HG: Cutting edge: regulation of $\mathrm{CD} 8(+) \mathrm{T}$ cell proliferation by $2 \mathrm{~B} 4 / \mathrm{CD} 48$ interactions. J Immunol 2001, 167(12):6706-6710.

32. Schlaphoff V, Lunemann S, Suneetha PV, Jaroszewicz J, Grabowski J, Dietz J, Helfritz F, Bektas H, Sarrazin C, Manns MP, Cornberg M, Wedemeyer H: Dual function of the NK cell receptor 2B4 (CD244) in the regulation of HCV-specific CD8+ T cells. PLoS Pathog 2011, 7(5):e1002045.

33. Wherry EJ, Ha SJ, Kaech SM, Haining WN, Sarkar S, Kalia V, Subramaniam S, Blattman JN, Barber DL, Ahmed R: Molecular signature of CD8+ T cell exhaustion during chronic viral infection. Immunity 2007, 27(4):670-684.

34. Benson DM, Bakan CE, Mishra A, Hofmeister CC, Efebera Y, Becknell B, Baiocchi RA, Zhang J, Yu J, Smith MK, Greenfield CN, Porcu P, Devine SM, Rotem-Yehudar R, Lozanski G, Byrd JC, Caligiuri MA: The PD-1/PD-L1 axis modulates the natural killer cell versus multiple myeloma effect: a therapeutic target for CT-011, a novel monoclonal anti-PD-1 antibody. Blood 2010, 116(13):2286-2294.

35. Hallett WHD, Jing W, Drobyski WR, Johnson BD: Immunosuppressive effects of multiple myeloma are overcome by PD-L1 blockade. Biol Blood Marrow Transplant 2011, 17(8):1133-1145.

36. Kuranda K, Berthon C, Dupont C, Wolowiec D, Leleu X, Polakowska R, Jouy N, Quesnel B: A subpopulation of malignant CD34+CD138+B7-H1+ plasma cells is present in multiple myeloma patients. Exp Hematol 2010, 38(2):124-131.

37. Liu J, Hamrouni A, Wolowiec D, Coiteux V, Kuliczkowski K, Hetuin D, Saudemont A, Quesnel B: Plasma cells from multiple myeloma patients express B7-H1 (PD-L1) and increase expression after stimulation with IFN-\{gamma\} and TLR ligands via a MyD88-, TRAF6-, and MEK-dependent pathway. Blood 2007, 110(1):296-304

38. Rosenblatt J, Glotzbecker B, Mills H, Vasir B, Tzachanis D, Levine JD, Joyce RM, Wellenstein K, Keefe W, Schickler M, Rotem-Yehudar R, Kufe D, Avigan D: PD-1 blockade by CT-011, anti-PD-1 antibody, enhances ex vivo T-cell responses to autologous dendritic cell/myeloma fusion vaccine. $\mathrm{J}$ Immunother 2011, 34(5):409-418.
39. Kearl TJ, Jing W, Gershan JA, Johnson BD: Programmed Death Receptor-1/ Programmed Death Receptor Ligand-1 Blockade after Transient Lymphodepletion to Treat Myeloma. J Immuno/ 2013, 190(11):5620-5628.

40. Legat A, Speiser DE, Pircher H, Zehn D, Fuertes Marraco SA: Inhibitory receptor expression depends more dominantly on differentiation and activation than "exhaustion" of human CD8 T cells. Front Immunol 2013, 4:455.

41. Fourcade J, Sun Z, Pagliano O, Chauvin J-M, Sander C, Janjic B, Tarhini AA, Tawbi HA, Kirkwood JM, Moschos S, Wang H, Guillaume P, Luescher IF, Krieg A, Anderson AC, Kuchroo VK, Zarour HM: PD-1 and TIM-3 regulate the expansion of tumor antigen-specific CD8+ T cells induced by melanoma vaccines. Cancer Res 2014, 74(4):1045-1055

42. Gros A, Robbins PF, Yao X, Li YF, Turcotte S, Tran E, Wunderlich JR, Mixon A, Farid S, Dudley ME, Hanada K-I, Almeida JR, Darko S, Douek DC, Yang JC, Rosenberg SA: PD-1 identifies the patient-specific CD8+ tumor-reactive repertoire infiltrating human tumors. J Clin Invest 2014, 124(5):2246-2259.

43. Baghdadi $M$, Nagao $H$, Yoshiyama $H$, Akiba H, Yagita $H$, Dosaka-Akita $H$, Jinushi M: Combined blockade of TIM-3 and TIM-4 augments cancer vaccine efficacy against established melanomas. Cancer Immunol Immunother 2013, 62(4):629-637.

44. Duraiswamy J, Freeman GJ, Coukos G: Dual blockade of PD-1 and CTLA-4 combined with tumor vaccine effectively restores $\mathrm{T}$-cell rejection function in tumors-response. Cancer Res 2014, 74(2):633-634. discussion 635.

45. Goding SR, Wilson KA, Xie Y, Harris KM, Baxi A, Akpinarli A, Fulton A, Tamada K, Strome SE, Antony PA: Restoring immune function of tumor-specific CD4+ T cells during recurrence of melanoma. J Immunol 2013, 190(9):4899-4909.

46. Bos R, Marquardt KL, Cheung J, Sherman LA: Functional differences between low- and high-affinity CD8(+) T cells in the tumor environment. Oncoimmunology 2012, 1(8):1239-1247.

47. Park HJ, Kusnadi A, Lee E-J, Kim WW, Cho BC, Lee IJ, Seong J, Ha S-J: Tumor-infiltrating regulatory $T$ cells delineated by upregulation of PD-1 and inhibitory receptors. Cell Immunol 2012, 278(1-2):76-83.

48. Curran MA, Montalvo W, Yagita H, Allison JP: PD-1 and CTLA-4 combination blockade expands infiltrating $T$ cells and reduces regulatory $T$ and myeloid cells within B16 melanoma tumors. Proc Natl Acad Sci U S A 2010, 107(9):4275-4280.

49. Mangsbo SM, Sandin LC, Anger K, Korman AJ, Loskog A, Tötterman TH: Enhanced tumor eradication by combining CTLA-4 or PD-1 blockade with CpG therapy. J Immunother 2010, 33(3):225-235.

50. Yu P, Steel JC, Zhang M, Morris JC, Waldmann TA: Simultaneous blockade of multiple immune system inhibitory checkpoints enhances antitumor activity mediated by interleukin-15 in a murine metastatic colon carcinoma model. Clin Cancer Res 2010, 16(24):6019-6028.

51. Allard B, Pommey S, Smyth MJ, Stagg J: Targeting CD73 enhances the antitumor activity of Anti-PD-1 and Anti-CTLA-4 mAbs. Clin Cancer Res 2013, 19(20):5626-5635.

52. Berrien-Elliott MM, Jackson SR, Meyer JM, Rouskey CJ, Nguyen T-LM, Yagita H, Greenberg PD, Dipaolo RJ, Teague RM: Durable adoptive immunotherapy for leukemia produced by manipulation of multiple regulatory pathways of CD8+ T-cell tolerance. Cancer Res 2013, 73(2):605-616.

53. Baitsch L, Baumgaertner $P$, Devêvre E, Raghav SK, Legat $A$, Barba L, Wieckowski S, Bouzourene H, Deplancke B, Romero P, Rufer N, Speiser DE: Exhaustion of tumor-specific $\mathrm{CD}^{+} \mathrm{T}$ cells in metastases from melanoma patients. J Clin Invest 2011, 121(6):2350-2360.

54. Crawford A, Angelosanto JM, Kao C, Doering TA, Odorizzi PM, Barnett BE Wherry EJ: Molecular and transcriptional basis of CD4(+) T cell dysfunction during chronic infection. Immunity 2014, 40(2):289-302.

55. Odorizzi PM, Wherry EJ: Inhibitory receptors on lymphocytes: insights from infections. J Immunol 2012, 188(7):2957-2965.

56. Wherry EJ: T cell exhaustion. Nat Immunol 2011, 12(6):492-499.

57. Yi JS, Cox MA, Zajac AJ: T-cell exhaustion: characteristics, causes and conversion. Immunology 2010, 129(4):474-481.

58. Duraiswamy J, Ibegbu CC, Masopust D, Miller JD, Araki K, Doho GH, Tata P, Gupta S, Zilliox MJ, Nakaya HI, Pulendran B, Haining WN, Freeman GJ, Ahmed R: Phenotype, function, and gene expression profiles of programmed death-1(hi) CD8 T cells in healthy human adults. J Immunol 2011, 186(7):4200-4212.

59. Baitsch L, Fuertes Marraco SA, Legat A, Meyer C, Speiser DE: The three main stumbling blocks for anticancer T cells. Trends Immunol 2012, 33(7):364-372.

60. Mittal R, Wagener M, Breed ER, Liang Z, Yoseph BP, Burd EM, Farris AB 3rd Coopersmith CM, Ford ML: Phenotypic T cell exhaustion in a murine model of bacterial infection in the setting of pre-existing malignancy. Plos One 2014, 9(5):e93523. 
61. Gao N, Schwartzberg P, Wilder JA, Blazar BR, Yuan D: B cell induction of IL-13 expression in NK cells: role of CD244 and SLAM-associated protein. $J$ Immunol 2006, 176(5):2758-2764.

62. Hosen N, Ichihara H, Mugitani A, Aoyama Y, Fukuda Y, Kishida S, Matsuoka Y, Nakajima H, Kawakami M, Yamagami T, Fuji S, Tamaki H, Nakao T, Nishida S, Tsuboi A, lida S, Hino M, Oka Y, Oji Y, Sugiyama H: CD48 as a novel molecular target for antibody therapy in multiple myeloma. Br J Haematol 2012, 156(2):213-224.

63. Di Giacomo AM, Biagioli M, Maio M: The emerging toxicity profiles of anti-CTLA-4 antibodies across clinical indications. Semin Oncol 2010, 37(5):499-507.

64. Brahmer JR, Drake CG, Wollner I, Powderly JD, Picus J, Sharfman WH, Stankevich E, Pons A, Salay TM, McMiller TL, Gilson MM, Wang C, Selby M, Taube JM, Anders R, Chen L, Korman AJ, Pardoll DM, Lowy I, Topalian SL: Phase I study of single-agent anti-programmed death-1 (MDX-1106) in refractory solid tumors: safety, clinical activity, pharmacodynamics, and immunologic correlates. J Clin Oncol 2010, 28(19):3167-3175.

65. Redmond WL, Linch SN, Kasiewicz MJ: Combined targeting of constimulatory (OX40) and coinhibitory (CTLA-4) pathways elicits potent effector T cells capable of driving robust antitumor immunity. Cancer Immunol Res 2014, 2(2):142-153.

\section{Submit your next manuscript to BioMed Central and take full advantage of:}

- Convenient online submission

- Thorough peer review

- No space constraints or color figure charges

- Immediate publication on acceptance

- Inclusion in PubMed, CAS, Scopus and Google Scholar

- Research which is freely available for redistribution 